\title{
Persian Love Poetry
}

Vesta Sarkhosh Curtis and Sheila R. Canby, eds. Northampton, Massachusetts: Interlink Books, 2006. 96 pages.

This little book is a beguiling collection of Persian love poems drawn from both classical and modern poetry, but united by the theme of love in its myriad interpretations. Included are poems that explore the spiritual love between humans and God, the magical love between lovers or spouses, the affectionate love between family members and between friends, and even the patriotic love for one's homeland. Each poem is accompanied with a precious Persian chef d'oeuvre from the British Museum and, in particular, 
numerous illustrations of Persian miniatures. The editors come to this subject with vast expertise: Vesta Sarkhosh Curtis is curator of Islamic and Iranian coins in the British Museum, and Sheila R. Canby is an assistant keeper in the British Museum specializing in Islamic Iran. Both have published on Persian art, art history, archaeology, and myths, among other topics. Their aim is not to produce a well-researched and exhaustive collection of Persian love poetry, but rather "to encourage readers to delve further into the wealth of Persian literature" (p. 5). With its modest aim of capturing the interest of novice western readers, theirs is a delightful book that charms its way to success.

As explained in the "Introduction," Iranians and other Persian (Farsi) speakers treasure poetry not only because of the beauty of the poetic language itself, but also because they derive joy and comfort from the poets' perspective toward the world. The most famous Persian poets often have a mystical (Sufi) viewpoint toward life, whereby passion is a path to reach God and the truth. Interwoven into the people's social consciousness, poetry holds a revered place in Persian culture. A single verse from the best-known Persian poems can capture an idea with elegant brevity. Iranians and other Persian (Farsi) speakers still recite poetry as a succinct and powerful way to express a point, thought, or emotion. To explain how deeply embedded poetry is in the Persian psyche, many oft-quoted proverbs draw much of their meaning and message from Persian poetry.

Under the section "Language," the editors delineate the tenacity of the Indo-European language known as Persian (Farsi) to evolve and thrive despite the onslaught of Arabic that accompanied the Arab conquest of Iran in the mid-seventh century. They go on to explain that Persian proper is now mainly found in Iran, Afghanistan, and Tajikistan. In "Poetic Forms," the editors provide a brief explanation of the various poetic forms, such as the $g h a$ zal and the masnavi, that gives the uninitiated an entry point into the study of Persian poetry. Then in "History and Legend," they summarize the most salient events and developments in the history of Persian poetry and legend.

Another section on "Women Poets" describes the accomplishments of female poets. "A strong sense of protest and individual engagement" (p. 12) permeates the works of these exceptional poets. A common thread of resistance runs through the works of twentieth-century and medieval female voices. As Parvin Jahanbani implies, she is among those "Women who / Love the raw passion of love / ... Women who do not hide / Their feelings in the corners of their scarves or behind their veils / Or under the carpet" (p. 90). Finally the "Biographical Notes," "Suggested Reading," and "Illustra- 
tion References" at the book's end are helpful sources of information for those readers whose appetites have been whetted for further study.

Even a quick perusal of these collected poems reveals that Persian love poetry is intensely passionate and that exaggerating one's love is an accepted rule. For example, in his poem on page 32, Baba Tahir Uryan asks for a dagger with which to pierce his eyes and thereby destroy his sight so that he can no longer see (and therefore no longer desire) his unrequited love. To a western reader unfamiliar with the context, such poems can appear unrealistic and syrupy; to a Persian reader, such intense ardor makes complete sense.

Some of the collection's highlights are Rumi, Hafiz, Ferdausi, Khayyam, and Sa'di, who are recognized by many as the pillars of Persian poetry. It is surprising that Nima Yushij, the father of modern poetry, and Ahmad Shamloo, another giant in the same field, are missing. After all, it was Yushij who introduced a whole new range of innovative techniques and forms to differentiate the modern from the old, who liberated Persian poetry and released it from classical prosody (the study of poetic meters and versification): "I have flooded the nest of ants." Why did the editors not include Shamloo, Sohrab Sepehri, and Siavesh Kesrai? One questions the rationale behind including lesser-known poets at the cost of neglecting the pioneers and stars of modern poetry.

A table of contents would have been helpful, as would have been titles to accompany the poems. For example, on page 72 the editors give us an excerpt from a poem by showcasing lines that start with "Why do you ask me the colour of his eyes?" However, by not revealing the poem's title, readers cannot easily refer to Forough Farrokhzad's original poem. On a similar note, the explanation below each poem is for the purpose of explaining the accompanying painting and, unfortunately, says nothing about the poem.

A pleasure to browse through, Persian Love Poetry is beautiful, both in appearance and in content. This book will entice its readers into the rose garden of Persian poetry so that they will become intoxicated by the fragrance of its many flowers.

David Armani

Graduate Student, Comparative International Education Ontario Institute for Studies in Education, University of Toronto, Canada

Louise Gormley Sessional Lecturer in Research Methodologies Brock University, St. Catharines, Ontario, Canada 